JOTE Volume 2 Nomor 1 Tahun 2020 Halaman 125-136 JOURNAL ON TEACHER EDUCATION Research \& Learning in Faculty of Education

\title{
PERAN ORANGTUA DALAM MENANAMKAN IBADAH SHALAT PADA ANAK USIA DINI DI DESA GERBANG SARI, KECAMATAN TAPUNG HILIR KABUPATEN KAMPAR
}

\author{
Faridayanti ${ }^{1}$, Joni ${ }^{2}$, Vigi Indah Permatasari ${ }^{3}$ \\ Program Studi Pendidikan Guru Pendidikan Anak Usia Dini, \\ Fakultas IImu Pendidikan, Universitas Pahlawan Tuanku Tambusai \\ Email : yantifarida910@gmail.com
}

\begin{abstract}
Abstrak
Peran orangtua dalam menanamkan ibadah shalat pada anak usia dini sangatlah penting khususnya bagi warga desa gerbang sari kecamatan tapung hilir kabupaten Kampar. Karena dalam mendidik anak adalah kewajiban bagi orangtua dari lahir hingga dewasa. Anak adalah sebuah anugrah dan titipan dari allah SWT sehingga kita sebagai orangtua sangat berperan penting dalam membentuk jiwa dan akhlak serta kewajiban sebagai umat islam adalah shalat. Penelitian ini bertujuan untuk mendapatkan informasi tentang bagaimana pentingnya peran orangtua dalam menanamkan ibadah shalat pada anak usia dini serta faktor pendukung dan penghambat. Lokasi penilitian peran orangtua dalam menanamkan ibadah shalat pada anak usia dini adalah di desa gerbang sari kecamatan tapung hilir kabupaten Kampar, dengan metode deskriptif kualitatif. Teknik pengumpulan data dengan cara langsung turun kelapangan melakukan wawancara dan observasi berdasarkan hasil penelitian menunjukkan bahwa orangtua memiliki peran penting dalam mendidik anaknya apalagi mendidik menanamkan ibadah shalat, upaya yang harus dilakukan orangtua dengan cara memberi contoh langsung dalam melakukan ibadah shalat serta hadiah pujian-pujian yang bersifat mendukung serta memotivasi secara langsung.
\end{abstract}

Kata kunci: Peran Orangtua, Menanamkan Ibadah Shalat

\section{Abstract}

The role in instilling prayer worship in early childhood is very important, especially for the residents of the gateway sari village, tapung downstream sub-district, Kampar district. Because in educating children is an obligation for parents from birth to adulthood. Children are a gift and a gift from Allah SWT so that we as parents who play a very important role in shaping the soul and morals and obligation as Muslims are prayer. This study aims to obtain information on how important the role of parents is in instilling prayer prayers in early childhood as well as supporting and inhibiting factors. The location of the research on the role of parents in instilling prayer worship in early childhood is in the village of gates sari, tapung downstream sub-district, Kampar district, with a qualitative descriptive method. Technique of data by directly going down to the field of conducting interviews and observations based on the results of the research shows that someone who has an important role in educating their children, let alone educating them to instill prayer, the efforts that parents must make by 
giving direct examples in praying and giving gifts directly supportive and motivating.

Keywords: The role of parents, instilling prayer services

\section{PENDAHULUAN}

Keluarga merupakan salah satu lembaga pendidikan yang pertama dan paling utama dalam diri seorang anak, karena seorang anak dilahirkan dan dibesarkan dari sebuah keluarga, serta akan berkembang menuju dewasa. Keluarga merupakan kelompok terkecil dari masyarakat, dimana dengan adanya keluarga tersebut akan terbentuk suatu masyarakat yang baik ataupun tatanan masyarakat yang buruk. Hal ini datang dari keluarga itu sendiri bagaimana keluarga tersebut bisa menjadikan seluruh anggota keluarganya menjadi seseorang yang memiliki keimanan, kesopanan dan sekaligus berpengetahuan yang luas. Dengan kata lain keluarga lah yang memiliki tugas dan tanggung jawab dalam menentukan kemana keluarga itu akan dibawa, warna apa yang harus diberikan kepada keluarga, dan isi apa yang akan diberikan kepada keluarga itu.

Peranan keluarga paling utama dan pertama yaitu dalam menanamkan nilai-nilai keagamaan, untuk menanamkan nilai-nilai agama kepada anak tidaklah mudah dan membutuhkan waktu dan kesabaran yang tinggi, tidak hanya sesekali dalam menanamkan nilai-nilai agama pada anak tetapi seharusnya secara terus-menerus dan tidak terputus.

Dalam hal ini orang tua memiliki peran yang sangat penting, serta orang tua merupakan guru pertama dan utama bagi pendidikan anak. Maka orang tualah sebagai kunci utama keberhasilan seorang anak. Langkah pertama merupakan hal penting yang harus diperhatikan dan dijaga sebaik-baiknya, karena sesungguhnya seorang anak diciptakan dalam keadaan siap untuk menerima kebaikan dan keburukan. Tiada lain hanya kedua orangtuanyalah yang membuatnya cenderung pada salah satu di antarakeduanya, Rahman (2005:23).

Menurut Zakiah Daradjat (2005:69) bahwa perkembangan agama pada anak sangat ditentukan oleh pendidikan dan pengalaman yang dilaluinya, terutama pada masa pertumbuhan yang pertama (usia0-12 tahun). Masa yang menentukan bagi pertumbuhan perkembangan agama anak untuk masa berikutnya. Karena itu, anak yang sering mendapatkan didikan agama dan mempunyai pengalaman keagamaan, maka setelah dewasa anak akan cenderung berikap positif terhadap agama, demikian sebaliknya anak yang tidak pernah mendapat didikan agama dan tidak berpengalaman dalam keagamaan, maka setelah dewasa anak tersebut akan cenderung bersikap negatif terhadapagamannya.

Anak merupakan amanat Allah SWT, maka wajib kita perlakukan dan didik dengan sebaik-baiknya.Mendidik anak dengan baik dan benar berarti menumbuhkembangkan totalitas potensi anak secara wajar. Potensi jasmaniah dan potensi rohaniah anak diupayakan tumbuh dan berkembang secara selaras, serasi dan seimbang. Dalam rangka membentuk anak yang 
shaleh atau shalihah, yakni anak yangmenjalin hubungan baik dengan Allah SWT, dan dengan sesama makhluk-Nya, maka pokok-pokok yang harus diberikan tiada lain adalah ajaran Islam. Menurut para ulama, ajaran Islam secara garis besar dapat dikelompokkan menjadi tiga, yakni akidah, ibadah dan akhlak. Oleh karena itu orang tua sebagai pendidik pertama bagi anak sebaiknya juga memiliki kemampuan mengenai penguasaan akidah, ibadah danakhlak, Sulaiman (2012:4).

Mengingat penting serta kompleksnya masalah keberagamaan anakmaka orang tua sebaiknyamenanamkan keagaaman sejak dini, untuk memperkokoh pondasi yang dimiliki anak sehingga di kemudian hari anak tidak terpengaruh akan lingkungan luar rumah. Sejak lahir bahkan masih dalam kandungan seorang anak sudah mulai diperkenalkan dengan keagamaan oleh orang tuanya.Dengan harapan kelak anak tersebut dapat mengikuti dan mengamalkan keagaamaan tersebut dengan sendirinya. Tidak mudah orang tua menanamkan keagamaan, dalam bidang keagamaan, orang tua memiliki tanggung jawab yang besar terhadap anak sejak kecil seorang anak harusnya mulai diperkenalkan dan ditanamkan nilai-nilai keagamaan. Mulai daribelajar shalat, mengaji, membaca, menulisserta kefasihan lafal Arab dan bacaan al-Qur"an. Misalnya dalam bidang shalat yang merupakan kewajiban kita sebagai umat Islam untuk melaksanakannya.Orang tua memiliki perandan tanggungjawab yang besar dalam menanamkan ibadah shalat pada anak sejak dini. Al-Hakim dan Abu Daud meriwayatkan dari Ibnu Amr bin al-Ash ra. Rasulullah SAW. Bahwa beliau bersabda:

Artinya : "Suruhlah anak-anak mu mengerjakan shalat apabila mereka sudah berumurtujuh tahun dan pukullah mereka karena mereka meninggalkannya apabila umur mereka sudah mencapai sepuluh tahun dan pisah-pisahlah di antara mereka pada tempattidur." (HR.Abu Daud)

Berdasarkan hal diatas dapat dipahami bahwa orang tua memiliki kewajiban untuk mengajarkan ibadah shalat, membimbing dan melatih agar rajin beribadah shalat serta harus mampu memberikan dorongan agar anak mau melaksanakan shalat dengan sebaik-baiknya dalam kehidupannya. Selanjutnya dikemukakan juga bahwa dorongan untuk menjalankan ibadah shalat bagi anak harus dicari oleh orang tuanya sebagaimana orang tua harus meniru dan mencontoh tauladan dari Luqman Al Hakim yang telah difirmankan oleh Allah SWT dalam Al Qur"an surat Luqman ayat 17 yang berbunyi:

Artinya : "Hai anakku, Dirikanlah shalat dan suruhlah (manusia) mengerjakan yang baik dan cegahlah (mereka) dari perbuatan yang munkar dan Bersabarlah terhadap apa yang menimpa kamu. Sesungguhnya yang demikian itu termasuk hal-hal yang diwajibkan (oleh Allah)." (Qs. Luqman31:17)

Dengan demikian dapat dipahami bahwa setiap orang tua sudah seharusnya dapat menjalankan tugas dan kewajibannya dengan baikdalam membimbing ibadah shalat pada anaknya supaya tumbuh menjadi muslim yang sejati yang taat kepada Allah SWT, dan usahayang dilakukan oleh orang tua itu sangat berpengaruh pada keagamaan anak. Ibadah shalat merupakan 
kewajiban bagi setiap umat Islam untuk mengabdikan diri kepada Allah SWT, pengertian ibadah shalat adalah "ibadah yang dimulai dengan takbir dan di akhiri dengan salam". Ibadah shalat merupakan fardu'ain yang artinya setiap orang yang telah baligh dan berakal sehat memiliki kewajiban untuk menegakkan ibadah shalat.

Pada dasarnya kewajiban shalat itu difardhukan atas orang-orang yang telah baligh, dan terhadap anak kecil memang shalat belum diwajibkan, namun alangkah lebih baiknya kita sebagai orang tua menanamkan nilai keagamaan kepada anak terutama ibadah shalat pada anak sejak dini. Agar ketika ia menginjak usia tujuh tahun yaitu usia dimana anak sudah diharuskan menjalankan ibadah shalat, anak tersebut dapat terbiasa atau terlatih mengerjakan ibadah shalat, tanpa disuruh oleh orang tuanya dan dengan sendirinya anak akan menjalankan shalatnya karena sudah tertanam dalam diri anak tersebut.

Berangkat dari latar belakang di atas, maka kiranya sangat diperlukan dalam era sekarang ini bagi orang tua untuk menanamkan nilai keagamaan terutama ibadah shalat pada anak sejak usia dini. Karena agar ketika dewasa anak akan cenderung bersikap positif terhadap agamanya. Dari pemaparan tersebut maka penulis tertarik untuk melakukan penelitian terhadap masalah yang dituangkan dalam skripsi ini yang berjudul "Peran Orang Tua dalam Menanamkan Ibadah Shalat pada Anak Usia Dini di Desa Gerbang Sari, Kecamatan Tapung Hilir Kabupaten Kampar."

\section{METODE}

Penelitian ini akan dilakukan di Desa Gerbang Sari, Kecamatan Tapung Hilir, Kabupaten Kampar pada bulan Agustus - September 2020. Penelitian ini bersifat deskriptif artinya penelitian yang menggambarkan atau memaparkan objek tertentu dengan kata-kata secara jelas dan terperinci dengan penelitian yang penulis lakukan, Suryabrata (2010:147)

penelitian ini ditunjukan untuk mendeskripsikan fenomena- fenomena yang ada, baik fenomena alamiah maupun fenomena buatan manusia. Fenomena itu bisa berupa bentuk, aktivitas, perubahan, hubungan, kesamaan, dan perubahan antara fenomena yang satu dengan fenomena yang lainnya.Jadi penelitian deskriptif selain menggambarkan kejadian yang terjadi dalam masyarakat juga mengungkapkan data yang ada padanya dan juga memberikan analisis untuk memperoleh kejelasan dan kebenaran masalah yang dihadapi.

Penelitian ini menggunakan pendekatan kualitatif dengan jenis penelitian field research (penelitian lapangan).Secara terminologi penelitian pendekatan kualitatif merupakan prosedur penelitian yang menghasilkan data deskriptif berupa kata-kata tertulis atau lisan dari orang-orang dan pelaku yang dapat diamati, Moleong (2013:4). Field reseach berarti penelitian yang langsung dilakukan dilapangan atau responden, tujuannya adalah untuk mencari, menunjukkan atau membuktikan adanya hubungan antara fakta dan teori, Nasution (2006:5). 
Adapun keseluruhan sample dari kriteria yang telah disebutkan di atas maka penulis mendapatkan sample sebanyak 18 keluarga yang memiliki anak usia 6 tahun di Desa Gerbang Sari, Kecamatan Kampar, akan tetapi karena dibatasi faktor agama islam saja maka yang menjadi sample sebanyak 15 anak saja karena 3 anak dalam 3 keluarga beragama Kristen, yang kesemuanya dari RT 13.

\section{HASIL DAN PEMBAHASAN}

\section{A. DESKRIPSI TEMUAN PENELITIAN}

Pandangan Orang Tua Terhadap Penanaman Ibadah Sholat dan cara pembelajarannya serta teknik motivasi yang diterapkan

Dalam agama Islam, shalat bukan saja sebagai salah satu unsur agama Islam sebagaimana amalan-amalan yang lain, akan tetapi merupakan amalan yang pertama kali dihisab. Karena itu kedudukannya demikian penting dalam agama, maka shalat menjadi tempat bertumpu dan bergantung bagi amalanamalan yang lain, yang karenanya jika shalat seseorang itu rusak maka menurut agama Islam rusaklah seluruh amalannya, dan sebaliknya itu baik, maka baik pula seluruh amalannya. Keterangan diatas menunjukkan pentingnya menunaikan ibadah shalat lima waktu, karena itu sangat diperlukan peran orang tua dalam menanamkan ibadah shalat pada anak sejak dini.

Hal ini sejalan dengan pendapat Ibu Sunarti selaku orang tua dari Febry, tentang peran orang tua dalam menanamkan ibadah shalat pada anak sejak dini, pada keluarga tersebut peran yang dilakukan oleh Ibu Sunarti terlihat pada keseharian yang dilakukan pada anaknya dengan menggunakan pendekatan keteladanan yaitu memberikan contoh langsung, dan mengawasi anaknya pada saat melaksanakan ibadah shalat, baik itu di rumah maupun di masjid. Ibu Sunarti juga sering memberikan hadiah sebagai motivasi untuk anaknya dalam melaksanakan ibadah shalat, ketika Febry sedang tidak mau melaksanakan shalat.

Hal ini berdasarkan wawancara dengan lbu Sunarti tentang peran orang tua dalam menanamkan ibadah shalat pada anak usia dini, beliau mengatakan:

"Kalau yang kami lakukan buat Febry, kami tidak terlalu memaksakan jadi tergantung kondisi dia aja, tapi ya, kami selalu mengajak dia untuk shalat berjamaah, terus kami kasih contoh ke Febry bagaimana gerakan shalat yang benar, ya biar nanti besar nya dia sudah terbiasa menjalankan shalat"

Dari sini dapat disimpulkan bahwa, peran orang tua dalam menanamkan ibadah shalat pada anak usia dini sangat diperlukan yaitu dengan cara memberikan contoh atau mempraktekkan langsung kepada anak bagaimana cara shalat yang benar. Hal ini dikarenakan anak selalu meniru dan mempraktekkan apa yang ia lihat dalam lingkungannya. Dengan memberikan contoh langsung kepada anak diharapkan anak akan mengingat serta nantinya akan terbiasa menjalankan shalat tanpa harus disuruh oleh orang tuannya. 
Di TPA sudah diajarkan mengenai shalat, tata cara berwudhu, latihan membaca, menghafal do'a-do'a, dan menulis arab. Sehingga pada waktu yang telah ditentukan anak bisa melakukan shalat, berwudhu, bisa membaca, menghafal do'a-do'a, dan menulis arab dengan baik dan benar. Dengan harapan ketika anak dewasa kelak ia bisa mengamalkan dan menerapkan apa yang telah ia pelajari.

Hal ini pun kembali di tegaskan oleh lbu Supiah selaku orang tua dari Fathir dalam hasil wawancara dengan penulis, beliau mengemukakan:

"Kalau saya bimbing fathir shalat tak nasehati, tapi ya pelan-pelan dinasehatinya namanya juga anak kecil jadi ya harus sabar-sabar, biar anakku bisa mendengarkan terus bisa dibayangin apa maksud omongan dari orang tuanya"

Usaha dalam menanamkan ibadah shalat pada anak memang sudah tanggung jawab orang tua, tetapi tidak semua orang tua mampu untuk mendidiknya sendiri, hal ini bukan berarti orang tua lepas tangan dari permasalahan ini, akan tetapi orang tua mencari bantuan untuk membantu dirinya dalam menyelesaikan permasalahan yang ia hadapi. Dari penjelasan tersebut dapat disimpulkan bawha cara yang digunakan orang tua dalam menanamkan ibadah shalat pada anak sejak dini yaitu dengan cara menasehati. Hal ini dikarenakan, anak lebih suka dinasehati. Dengan nasehat yang tulus akan berpengaruh terhadap jiwa anak, sehingga akan meninggalkan bekal yang mendalam.

Ibu Ayu orang tua dari Teguh pun sependapat saat memberikan pernyataannya dalam wawancara dengan penulis bahwa dalam hal pemberian nasehat orang tua harus dapat memperhatikan serta menyesuaikan waktu yang tepat dan sesuai dalam pemberian nasehat dan pemberian pemahaman pada anak seperti pada waktu santai keluarga dan di saat suasana hati anak merasa gembira dan senang. Dalam peryataan lain beliau juga mengemukakan tentang peran orang tua dalam menanamkan ibadah shalat pada anak sejak dini:

"Biasanya kalau kami membimbing anak tak perhatikan, jadi kan anakku seneng, oh aku di perhatikan ibuku misalnya, terus sekarang tak masukki ke TPA biar bisa bantu meningkatkan pemahaman tentang agama, meskipun aku sama bapaknya repot sama kerjaan, tapi tetep tak sempetin buat ngajarin dia"

Dalam penjelasan tersebut dapat disimpulkan bahwa cara yang digunakan orang tua selain memberikan nasehat adalah dengan bentuk memperhatikan si anak tersebut. Dikarenakan, jika sang anak mendapatkan perhatian dari orang tua, maka sang anak akan merasa dirinya di bimbing, dan dari bentuk memperhatikan bisa menghasilkan hasil yang positif, karena anak cenderung kepada kebaikan.Meskipun dengan adanya kesibukan dari orang tua tapi lbu dari 2 anak ini selalu menyempatkan untuk membimbing anaknya kearah yang benar.

Dalam hal membimbing anak, orang tua harus mengerti anak sebelum memberikan pemahaman terutama perihal ibadah shalat, oleh karena itu sesering mungkin orang tua harus mengajak anak untuk sharing, berbagi keluh 
kesah dan pendapat, dengan demikian anak merasa dihargai oleh kedua orang tuanya.Anak paling menyukai jika ayah dan ibunya memuji serta membanggakan apalagi jika memberikan pujian berupa kata-kata yang baik. Tidak hanya memberikan nasehat dan contoh pada anak mengenai ibadah shalat tetapi orang tua juga harus menerapkan kedisiplinan kepada anak dengan cara membiasakan anak itu melakukan kegiatan yang baik dan berguna, hal ini diungkapkan oleh Ibu Nurlaila yaitu ibu dari Rahmad dalam wawancara dengan peneliti:

"Kalau aku mendidik anakku, dibiasakan buat shalat berjamaah bareng sama ibu bapaknya dirumah kalau enggak ya ikut bapak nya shalat berjamaah di masjid."

Dari penjelasan Ibu Nurlaila dapat disimpulkan bahwa peran orang tua dalam menanamkan shalat pada anak bukan hanya memberikan contoh kepada anak tetapi juga harus diiringi dengan membiasakan si anak tersebut dalam melaksanakan shalat. Selain itu, Ibu Nurlaila juga mengatakan ketika orang tua hendak melakukan shalat sang anak ikut dengan sendirinya,tanpa diperintah dari orang tua. Dari sini jelas bahwa, kesadaran untuk melakukan hal yang baik itu dimulai dari dirinya sendiri atau sejak usia dini. Sebagaimana disampaikan saat wawancara:

"Kalau aku tak nasehati, tak kasih pengawasan sama anaknya, kadang kalau dia bantah omongan ku ya tak marahi, biar anakku takut jadi pas besarnya dia enggak berani melawan orang tua"

Peran yang diberikan oleh orang tua sangat menentukan keberhasilan anak, untuk itu orang tua harus sadar dan harus berlomba-lomba untuk mendidik anak-anaknya, selain itu orang tua juga perlu memberikan perhatian, nasehat, hukuman dan pendidikan bantuan (pendidikan TPA/ yang lain) supaya sang anak memiliki pengetahuan luas

Berdasarkan hasil wawancara dengan Ibu Susanti orang tua dari Danis, diketahui bahwa Orang tua harus berupaya terus dalam masalah pendidikan terutama pendidikan agama dan menjadi contoh atau teladan dalam pelaksanaan ibadah sholat supaya ketika dewasa nanti anak akan terhindar dari perbuatan mazdmumah dan akan menunjukkan cita-cita menjadi manusia yang berguna, sebagaimana hasil wawancara dengan peneliti:

"Kalau kami mendidiknya ya kami ajak anak kami untuk shalat bareng, kalau tidak dirumah ya kadang di masjid. Pokoknya kami biasakan untuk shalat, biar nanti kalau dia sudah besar bisa rajin beribadah"

Dari sini dapat disimpulkan bahwa dengan membiasakan anak untuk beribadah, maka akan tumbuh dengan iman yang benar, berhiaskan diri dengan etika islami, bahkan pada sampai puncak nilai spritual yang tinggi serta berkepribadian yang utama.

Hal lain diungkapkan oleh Ibu Siti orang tua dari Fazri, Ibu Siti mengatakan :

"Kalau saya tak kasih pengawasan ke anaknya, kalau waktu shalat ya shalat terkadang anakku ya sudah mengerti sendiri oh ini waktu nya 


\section{shalat begitu"}

Dari pengakuan lbu Siti dapat disimpulkan bahwa dengan memberikan pengawasan akan membuah kan hasil yang positif, karena anak kecil cenderung dengan kebaikan, sehingga sangat mudah untuk menjadibaik.

Kemudian wawancara peneliti dengan Ibu Ginem orangtua dari Dimas tentang peran orang tua dalam menanamkan ibadah shalat pada anak usia dini, menjelaskan bahwa:

"Kalau saya sambil mengajarkan shalat jamaah dirumah saya juga nitipin anak saya ke TPA, jadi anaknya juga tambah semangat belajar agamanya, terkadang ya saya sambil nasehatin biar anaknya nggk kayak anak-anak yang lain yang nggk tau shalat"

Dapat disimpulkan dari wawancara tersebut bahwa orang tua harus benar-benar memperhatikan anak dalam masalah pendidikan khususnya pendidikan agama dan akhlak, orang tua harus berupaya sekuat tenaga dalam mendidiknya, pendidikan orang tua merupakan penentu bagi keberhasilan dan masa depan anaknya, jadi sebaik-baiknya pendidikan yaitu pendidikan dari orang tua bukan yang lain.

Adapun menurut Ibu Painem ibunda dari Ezy, dia menganggap pengajarkan anak shalat adalah penting karena solat adalah tiang agama, dia mengajarkan anaknya sholat dengan cara memberi contoh lannsung dari menyeruh anaknya ke masjid untuk sholat berjamaah, jadi disimpulkan dari wawancara bersama Ibu Painem bahwa pembelajaran sholat bagi anak adalah penting dengan cara memberi contoh sholat dan memberi teladan

Kemudian Ibu Mailina ibu dari Erik berpendapat bawah pengajaran sholat penting bagi anak karena itu ajaran pertama dalam agama islam, selanjutnya anak diajarkan sholat dengan cara membiasakan anak untuk melakukan sholat, jika menunjukkan kemajuan dalam sholat misalkan Erik rajin sholat atau pergi ke masjid maka ibu Mailina dan suami tak sungkan-sungkan memberikan hadiah bagi anaknya

Maka oleh peneliti disimpulkan dari wawancara bersama ibu Mailina bahwa mengajarkan anak sholat penting, caranya anak dibiasakan dan jika anak menunjukkan kemajuan maka akan diberikan hadiah sebagai motivasi.

Lalu dari lbu Sinta yaitu orang tua dari Dandi menyampaikan bahwa mengajarkan anak sholat adalah penting karena itu yang pertama kali dilihat oleh masyarakat (rajin sholat atau tidak), kemudia caranya ya dengan menyuruh anak sholat aja karena sudah sholat sudah diajarkan di sekolah, ibaratnya orang tua tinggal melanjutkan perintah gurunya dari sekolah, cara memotivasinya dengan memberi jajan kalau rajin sholat kalau tak rajin kurangi uang jajan biasanya begitu manjur

Maka dari wawancara bersama ibu dana dapat disimpulkan bahwa pengejarkan anak sholat adalah penting, kemudia caranya dengan menyuruh anak mengerjakan sholat dan uang jajan dijadikan semacam motivasi bagi Dandi

Sementara Ibu Achadiyah ibu dari Fata dalam wawancara menyampaikan bahwa menanamkan ibadah sholat bagi anak adalah penting, karena tuntunan 
dalam agama, caranya dengan praktik langsung (mengajak sholat) jika mau ikut dan rajin sholat maka diberi hadiah atau uang jajan diberi lebih.

Kesimpulan dari wawancara bersama lbu Achadiyah bahawa pembelajaran sholat itu penting, dan caranya dengan praktik langsung dan jika ikut atau rajin maka akan diberi hadiah atau uang jajan diberi lebih.

Adapun wawancara peneliti dengan Ibu Lasma yaitu orang tua dari Zahra menyampaikan jika mengajarkan anak sholat sejak dini adalah penting, karena itu adalah ibadah rutin berbeda dengan ibadah yang lain, caranya ya anak dibiasakan untuk sholat jamaah, jika rajin tentu diberi hadiah tapi tidak dijanjikan

Dari wawancara bersama lbu Lasma disimpulkan bawah pengajaran sholat sejak dini penting karena ibadah rutin, cara dengan pembiasaan sholat dan pemberian hadiah sebagai motivasinya. Jadi dapat disimpulkan dari wawancara dengan Ibu Rahmi bahwan pengajaran sholat anak adalah penting, caranya dengan membisakan anak sholat, lalu pemberian hadiah sebagai motivasi.

Adapun wawancara dengan Ibu Nanda yaitu orang tua dari Riski menyampaikan jika mengajarkan anak sholat adalah penting karena ajaran agama, caranya dengan praktik langsung, langsung mengajak anak sholat berjamaah, dan memberi hadiah jika memungkinkan.

Disimpulkan dari wawancara bersama lbu Nanda bawah pengajaran Sholat bagi anak wajib dengan cara praktik langsung dan memberi hadiah jika memungkinkan

Kemudian hasil wawancara penulis dengan Ibu Erna yaitu orang tua dari Qia menyampaikan bahwa pengajaran sholat bagi anak sangat penting sejak dini karena meurapakan tuntunan agama islam, caranya dengan membiasakan anak sholat sejak dini meskipun anak belum paham dan hafal gerakan sholatnya, kemudian anak dimotivasi dengan hadiah tapi tidak dijanjikan

Jadi kesimpulan wawancara dengan Ibu Erna bahwa pengajaran Sholat anak penting, caranya dengan membiasakan anak sholat dan memberi hadiah yang tidak dijanjikan sebagai motivasi

Wawan cara terakhir dengan Ibu Rahma yaitu Ibu dari Zira yang mengatakan jika mengajarkan anak ibadah sholat sejak dini adalah penting dengan alasan anak perumpuan akan semakin cantik jika sholatnya rajin, cara mengajarakan anak sholat dengan mengajaknya melakukan sholat berjamaah di rumah karena anak perempuan afdholnya sholat di rumah berbeda dengan anak laki-laki, dan memberi hadiah adalah hal yang penting agar anak jadi penurut dan mengikuti ajakan orang tua

Dari wawancara dengan lbu Rahma dapat disimpulkan bahwa mengajarkan anak sholat sejak dini adalah penting, dan cara dengan praktik langsung/memberi contoh di rumah lalu memberi hadiah adalah penting dalam hal ini.

Setiap orang tua mempunyai cara yang berbeda-beda dalam menanamkan pendidikan agama terutama perihal ibadah shalat pada anak, akan tetapi cara orang tua dalam memotivasi anak untuk melakasanakan ibadah 
shalat hampirlah sama, kebanyakan dari orang tua dalam memotivasi anaknya yaitu dengan cara memberikan hadiah, hal ini pun sama dengan yang dilakukan oleh ke lima narasumber yang ada di atas. Pemberian hadiah yaitu dengan memberikan suatu hal yang berharga kepada anak, seperti apabila anak melakukan perbuatan terpuji yang termasuk didalamnya perilaku yang mencerminkan kecerdasan emosi. Hal ini tentunya akan menyenangkan hati anak yang akan berdampak positif bagi perkembangan emosi anak dan dapat menanamkan rasa percaya diri dalam jiwa anak serta mendorong mereka untuk belajar bertingkah laku dengan baik.

Dengan adanya pemberian hadiah contohnya dengan yang dilakukan oleh kelima orang tua diatas, yaitu dengan memberikan hadiah berupa makanan kesukaan, barang kesukaan dan fasilitas yang memadai maka anak akan lebih semangat dalam belajar dan memudahkan ia dalam belajar agama dengan begitu kecakapan dalam belajar agama dan beribadah akan terwujud.

Kemudian fakta dari lbu Rahma yaitu lbu dari Zira, yang menyatakan faktor pendukung dan penghambat adalah: "Faktor pendukung karena ada kawannya yang rajin sholat sehingga ikut mau sholat juga, kadang-kadang juga diberi motivasi berupa hadiah, atau ulang tahunnya nanti dirayakan, adapun faktor penghambatnya adalah kesibukan orang tua, siaran TV"

\section{B. PEMBAHASAN}

Dari jabaran temuan di atas maka dapatlah diberi pembahasan sebagai berikut;

Dari ke 15 orang tua yang diwawancara oleh peneliti semuanya sepakat bahwa penanaman ibadah sholat sejak dini adalah penting namun alasanya yang berbeda-beda sesuai dengan pemahaman masing-masing orang tua yang diwancara ada yang beralasan agar anak terbiasa melaksanakan sholat sejak dini, ada yang beralasan karena seseorang pertama kali dilihat sholatnya, ada juga mengatakan sholat membentuk karakter seseorang, ada juga yang mengatakan karena sholat tuntunan agama, hal ini adalah fakta yang menggembirakan artinya bahwa orang tua dari 15 anak sudah memiliki pemahaman yang baik akan arti pentinnya menagajarkan anak sholat sedini mungkin.

Selanjutnya dari 15 orang tua yang diwawancara oleh peneliti mengenai cara/metode mengajarkan anak sholat memberikan jawaban yang berbeda-beda pula di antaranya adalah dengan pembiasaan jadi anak dibiasakan mengerjakan sholat baik secara individu atau secara berjamaah di masjid, adapula yang memberikan jawaban dengan keteladanan artinya orang tua yang menyuruh anaknya sholat sudah harus siap dengan pakaian sholat misalnya sudah memakai sarung baru mengajak anaknya sholat jadi mengajak sholat bukan menyuruh sholat, namun ada juga yang melalui nasehat dan anjuran saja.

Metode atau cara menanamkan sholat pada anak sudah sangat selaras dengan apa yang disampaikan oleh ismayanti dalam cara melatih dan mengenalkan sebagaiberikut (meskipun tidak semaua cara di lakukan orang tua): 
1. Teladan

2. Melatih berulang-ulang

3. Suasana nyaman dan aman

4. Tidak Memaksa tapiTegas Beri Arahan Dengan halus.

5. Tidak membanding-bandingkan

Kemudian dari 15 orang tua yang diwawancara oleh peneliti mengenai motivasi yang diberikan dalam mengajarkan anak sholat memberikan jawaban yang sepakat bahwa mereka memberikan motivasi (external) kepada anak agar rajin dalam melaksanakan ibadah sholat di antaranya motivasi memberikan hadiah (iming-iming hadiah), ada juga motivasinya dimasak masakan kesukaan anak, lalu ada juga motivasinya jika anak sholat diizinkan untuk main HP, kemudian ada juga motivasi berupa perayaan hari ulang tahun anak jika rajin sholat.

Mengenai memotivasi dalam mengajarkan anak agar mau melaksanakan ibadah shalat tidak semata-mata dengan motivasi external berapa hadiah karena motivasi external akan cepat berubah seriiring perubahan drive externalnya adapun motivasi yang lain yang dapat di antaranya:

1. Beri Teladan

2. Ajarkan Tata Cara.

3. Penyediaan Fasilitas

4. Pemberian Hadiah Dan Pujian.

Selanjutnya faktor penghambat terkuak fakta setelah dilakukan wawancara bersama 15 orang tua anak bahwa faktor yang paling dominan dalam menghambat anak melaksanakan ibadah sholat sejak dini adalah faktor main HP dan menonton siaran TV setelah itu baru faktor orang tua baik karena kesibukan orang tua dalam berkebum da nada juga faktor pengajian di masjid artinya anak ikut mengaji di masjid, adapun faktor penghambat sedapat mungkin mulai diatasi apa lagi faktor penghambat yang berupa bermain HP kalau mmenurut peneliti lihat hal tersebut sudah sampai pada tingkat kecanduan bermain HP, hal ini tanda dan gejala anak Anda kecanduan gadget (https://hellosehat.com/parenting/kesehatan-anak/anak-kecanduan-gadget/\#gref) adalah:

1. Keasyikan bermain gadget, hingga lupa waktu

2. Perilaku yang tidak nyaman ketika tidak bermain gadget.

3. Terus meningkatkan waktu bermain gadget dan mengabaikan instruksi orang tua.

4. Gagal untuk mengurangi atau berhenti bermain dengan gadget.

5. Kehilangan ketertarikan dengan dunia luar.

6. Tetap menggunakan gadget meskipun mengetahui konsekuensi negatif yang akan didapatkan.

7. Berbohong mengenai lama penggunaan gadget ke orang tua.

8. Pakai gadget untuk mengalihkan perasaan. 


\section{SIMPULAN}

Bedasarkan pembahasan yang dilakukan pada bab sebelumnya maka dengan ini peneliti dapat menyimpulan temuan sebagai berikut;

1. Semua orang tua dari 15 anak yang diwawancara sudah memiliki pemahaman yang baik akan pentingnya penanaman ibadah sholat pada anak sejak dini meski denangan alasan yang berbeda.

2. Ke 15 oarang tua menggunakan cara/metode yang berbeda-beda dalam menanamkan sholat pada anaknya yang kesemuanya adalah baik menurut peneliti

3. Kemudian dari 15 orang tua yang diwawancara oleh peneliti mengenai motivasi yang diberikan dalam mengajarkan anak sholat memberikan jawaban yang sepakat bahwa mereka memberikan motivasi (external) kepada anak agar rajin dalam melaksanakan ibadah sholat

4. Faktor pendukung yang ditemuakan dalam wawan cara bersama 15 orang tua adalah dorongan orang tua, dukungan peer group/kawan sebaya juga dipengaruhi lingkungan di mana anak mengaji, selanjutnya faktor penghambat yang lazim ditemukan/dominan adalah pengaruh HP dan tayangan TV

Orang tua dari 15 anak menurut peneliti sudah sangat berperan dalam menanamkan ibadah sholat pada anak mulai dari membiasakan, memberi teladan, memotivasi mendukung atau menjadi faktor pendukung

\section{DAFTAR PUSTAKA}

Al-Faruq, A. (2010). Mendidik Balita Mengenal Agama.Solo: Kiswah Media

Aly, H.N. (1999).IImu Pendidikan Islam.Jakarta: Logos

Amin, S.M. (2017). Menyiapkan Masa Depan Anak Secara Islami. Jakarta: Amzah

Arikunto, S. (2013).Prosedur Peneitian Suatu Pendekatan Praktek. Jakarta:Rineka Cipta

Ar-Ramadi, A. (2013). Pendidikan Cinta Untuk Anak. Solo: Aqwam.

Bachtiar, W. (1997).Metodologi Penelitian IImu Dakwah. Jakarta: logos

Bungi, B. (2010). Metodologi Penelitian Kualitatif, Cet.10. Jakarta:Rajawali Pers

Daradjat, Z. (1996). IImu Pendidikan Islam.Jakarta: Bumi Aksara

Daradjat, Z. (2005) Ilmu Jiwa Agama. Jakarta: Bulan Bintang

Hidayat, S. (2002).Metodologi Penelitian. Bandung: Mandar Maju 